\title{
ИСТОРИКО-ПРАВОВЫЕ АСПЕКТЫ СТАНОВЛЕНИЯ И РАЗВИТИЯ ИНСТИТУТА НАСЛЕДОВАНИЯ ПО ЗАКОНУ
}

\section{HISTORICAL AND LEGAL ASPECTS OF THE ESTABLISHMENT AND DEVELOPMENT OF THE INSTITUTE OF INHERITANCE BY LAW}

\section{A. Valevskaya}

Summary. The article is devoted to the analysis of genesis issues of inheritance relations with respect to such a basis as inheritance by law. The article explores the main stages of inheritance development according to the law, from ancient Roman jurisprudence to modern Russian legislation. The article reflects the peculiarities of the said basis of inheritance at the Soviet stage of national social development, regulated in Decrees, Civil Codes of the RSFSR1922 and 1964, etc. The peculiarities of inheritance under the law are noted in the current inheritance law, the regulated eight-level order of heirs who acquire the right to inherit on the basis of the gradual system recognized in Russia as the fundamental criterion of recognition to inheritance under the law of a certain relative has been studied.

Keywords: inheritance, historical sources, ancient Roman jurisprudence, succession order, gradual inheritance system.

\author{
Валевская Ангелина Анатольевна \\ К.ю.н., доцент, ФГБОУ ВО «Саратовская \\ государственная юридическая академия», г. Саратов \\ a.valevskaya@yandex.ru
}

Аннотация. Статья посвящена анализу вопросов генезиса отношений по наследованию в отношении такого основания, как наследование по закону. В статье исследованы основные этапы развития наследования по закону, начиная в древнеримской юриспруденции до современного российского законодательства. В статье отражены особенности названного основания наследования на советском этапе национального общественного развития, регламентированные в Декретах, в Гражданских кодексах РСФСР 1922 г. и 1964 г. и пр. Отмечены особенности наследования по закону в действующем наследственном праве, исследована регламентированная восьмиуровневая очередность наследников, приобретающих право наследования на основании градуальной системы, признанной в России в качестве основополагающего критерия признания к наследованию по закону определенного родственника.

Ключевые слова: наследование, исторические источники, древнеримская юриспруденция, очередность наследования, градуальная система наследования.

могло подлежать свободному завладению любым индивидом. Пережиток подобного понимания наследования был сохранен в ранней древнеримской юриспруденции, провозглашавшей, что в указанном контексте захват наследственного имущества - не преступление

Не представляется возможным сомневаться, что в качестве первого основания наследования в Древнем Риме, как и в иных цивилизациях, выступило наследование по закону (hereditas legitima). В силу изложенного, материальные блага умершего родственника оставалось в имущественной (наследственной) массе семьи, которая на протяжении длительного периода общественного развития с глубочайшей древности признавалась в качестве единственной законной обладательницей прав на наследство [3, с. 119].

Истоками нормативной регламентации наследования по закону в древнеримской юриспруденции, которая легла в основу континентального права в силу непревзойденности юридической техники, как и всего мирового сообщества, признаны Законы XII таблиц. Данный исторический памятник древнеримского цивильно- 
го права предусматривал оба основания наследования (по закону и по завещанию), при этом, наследование по закону осуществлялось в отсутствии завещания («si intestato moritur»), что впоследствии было признано одним из ведущих начал римского наследственного права.

Преторское древнеримское наследственное право, скорректировав правила наследственного преемства, приобрело особый патриархальный (агнатический) характер. В силу интердикта претора «interdictum quorum bonorum», помимо наследников, признаваемых таковыми законом, к наследованию могли быть признаны лица, указанные непосредственно претором. На данном историческом этапе были сформированы следующие фундаментальные основы наследования по закону: вступление в права наследования последующей очереди наследников в отсутствии принятия наследства предыдущей очередью; признание наследниками лиц с агнатическим и когнатическим родством (в силу повышения значения института брака).

В императорский период развития древнеримской юриспруденции в сфере наследования отмечено усиление когнатического родства, что нашло отражение в четырех очередях наследников по закону: первая очередь (unde liberi) -законные, усыновленные и приемные дети наследодателя; вторая (unde legitimi) - агнатические родственники; третья (unde cognati) - родственники по крови до шестой степени родства, в т.ч. матери наследодателя; четвертая очередь (unde vir et uxor) - переживший супруг наследодателя [3, с. 201].

Национальные памятники наследственного права свидетельствуют о том, что период зарождения российской государственности (IX - XI вв.) отмечен неустойчивостью института наследования. На наследственные правоотношения оказывали влияние постулаты византийского, римского права, противодействие между старославянскими обычаями наследования и византийскими правилами, отраженными в византийских международных договорах 911, 944, 971, 1043 г.г.

На данном историческом этапе наследование осуществлялось в соответствии с положениями Закона русского (упомянутого в договорах Руси и Византии), в первом кодифицированном акте Древней Руси - в Русской Правде. По Русской Правде, в которой наследованию было посвящено десять статей, наследование по закону осуществлялось в случаях отсутствия завещания. Наследственная масса имела название «статок» или «задница» - «то есть то, что оставляет позади себя отправляющийся в другой мир» [4, с. 69].

С развитием феодального строя в национальной юриспруденции положения о наследовании по закону нашли отражение в Псковской и Новгородской Судных грамотах 1467 г. и1456 г., в Судебнике 1497 г., в Грамоте Ивана Грозного 1550 г.,1589 г., в Уложении царя Алексея Михайловича 1649 г., в актах Петра I - Указы 1701 г., 1714 г., в Манифесте Екатерины II 1792 г. и др.

В процессе систематизации дореволюционного законодательства имперского исторического периода России - в части первой Т. Х Свода законов Российской империи 1832 г. [5, с. 155], как отмечал Д.И. Мейер, «лицо делается наследником двумя путями - или по завещанию, или по закону,- но как скоро достигает пункта, на котором делается наследником, то идет уже одним путем» [6, с. 64]. Тем не менее, необходимо признать: в данном кодифицированном источнике отсутствовала отдельная глава, посвященная наследованию,- именно в указанной связи, нормы о наследовании по закону были размещены в разделе «О порядке приобретения и утверждения прав на имущество в особенности».

На этапе советского периода российской государственности нормативные положения о наследовании по закону претерпевали изменения в зависимости от определенного исторического этапа, отличающегося идеологическими позициями, отношением законодателя к частной собственности, к институту брака: от попыток полной ликвидации института наследования (Декрет ВЦИК РСФСР 1918 г. «Об отмене наследования» [7]) до отмены максимума наследования (Постановление ЦИК и СНК СССР 1926 г. [8]) и расширения круга наследников по закону (Постановление ВЦИК и СНК РСФСР 1928 г. [9]), до прогрессивных законодательных инициатив, нашедших отражение в Гражданских кодексах РСФСР 1922 г. [10] и 1964 г. [11]

Кодифицированный акт 1922 г. предусматривал оба основания наследования. В отсутствии завещания, определявшего порядок раздела наследственного имущества в силу личного волеизъявления завещателя, наследственная масса подлежала распределению между наследниками по закону в тождественных долях. Законодатель дифференцировал правопреемников в наследственных правах по закону на отсутствующих (которые заявляли о наследственных правах) и присутствующих (наследник не заявлял суду об отказе от наследства и признавался принявшим наследство (ст. 429 ГК РСФСР 1922 г.).

С ликвидацией частной собственности отпала необходимость существования в дальнейшем различных ограничений наследственного правопреемства, в связи с чем, назревала реальная потребность привести наследственное право в соответствие с происходящими изменениями в социально-экономической жизни стра- 
ны. Однако решение данной задачи было отложено изза начала Великой Отечественной войны 1941 г., в связи с чем, только после ее окончания появилась возможность внести изменения в наследственное право, что нашло отражение в Указе Президиума Верховного Совета СССР 1945 г. «О наследниках по закону и по завещанию» [12].

В Указе Президиума Верховного Совета СССР от 14 марта 1945 г. расширялся круг наследников, в число которых включены родители, братья и сестры умершего; установлена очередность призвания к наследованию; при отсутствии наследников по закону наследодатель мог завещать свое имущество любому лицу [13]. Значительные изменения в наследовании по закону произошли в 1961 г. с принятием Основ гражданского законодательства Союза ССР и республик [14], что нашло отражение в Гражданском кодексе РСФСР 1964 г. путем установления четырех очередей наследников по закону.

В современной России в действующем кодифицированном акте гражданского законодательства [15] основной свод нормативов, определяющих рассматриваемое основание наследования в сторону императивной очередности, отражен в ст. 1141-1145, 1148 ГК РФ. Преобладающей в научном сообществе признана доктрина наследования по закону в качестве предполагаемой воли индивида - наследодателя. Отмечено: законодатель, устанавливая очередность наследников, стремится определить желание большинства наследодателей, исходя от идей гуманизма, семейных ценностей, позволяя, кроме того, экономить время и силы: потенциальный наследодатель, обладая информацией о содержании закона, осознает об отсутствии необходимости совершать завещание. В указанной связи, наследование по закону и в современной доктрине именуют «молчаливым завещанием» $[16$, с. 256].

В настоящее время в российском гражданском законодательстве регламентирована восьмиуровневая очередность правопреемников, приобретающих право наследования на основании градуальной системы, признанной в качестве основополагающего критерия признания к наследованию определенного родственника [17, с. 109]. Наследование, соответственно, осуществляется по правилам очередности, основанной на степени родства в корреляции с наследодателем. Степень родства при этом определяется числом рождений, которые отдаляют родственников (наследника и наследодателя) друг от друга. Рождение наследодателя в подобный разряд не включено [18, с. 7].

В наследственном праве на всех этапах развития юридической мысли и юриспруденции, таким образом, несмотря на особое значение завещания, традиционным выступает наследование по закону. Общепризнанным в современной России выступает предоставление ближайшего правомочия по наследованию по закону именно нисходящей родственной линии, состоящей из степеней, рождений, «простирающихся к потомству» [19, с. 344]. Однако, представляется, что нисходящие наследники (внуки наследодателя) также должны обладать преимущественным правом наследования по закону перед наследниками боковых линий, выступать наследниками первой очереди.

Представляется, что позиция законодателя по отношению к внукам в действующем праве несправедлива: данные родственники не только не включены в очередность наследников (наследуя по праву представления либо по завещанию), но и исключены от возможности наследования от дедушки (бабушки) в качестве нетрудоспособных иждивенцев, а также возможности принять наследство в силу п. 1 ст. 1158 ГК РФ (законодательный запрет отказа от наследства в пользу внуков). В результате, закон, допуская отказ от наследства в пользу родственников боковой линии родства, не призываемых к наследству, оставляет без наследства внуков, которые в силу национальной традиции, отношений между различными поколениями, пребывают в особой моральной связи поколений с бабушками и дедушками, которую представляется возможным признать национальным достоянием.

\section{ЛИТЕРАТУРА}

1. Гегель Г.В.Ф. Энциклопедия философских наук. М., 1977. Т. 2. 452 с.

2. Гегель Г. В. Введение в историю философии. Лекции по эстетике. Наука логики. М. Библиотека избранных сочинений. М., 1975. 600 с.

3. Перетерский И.С., Новицкий И. Б. Римское право. М., 2012.560 с.

4. Шершеневич Г. Ф. Учебник русского гражданского права (11 издание, 1-е посмертное, просмотренное и дополненное по поручению юридического факультета Императорского Московского университета) / В. А. Красноутский. М.: Изд-во Бр. Башмаковых, 1915. 315 с.

5. Свод законов Российской Империи. Том Х, ч. 1: Законы гражданские. Издание Собственной Его Императорского Величества канцелярии. СПб, 1900. С. 155.

6. Мейер, Д. И. Русское гражданское право. М., 1902.742 с.

7. Декрет ВЦИК от 14 (27) декабря 1918 г. «06 отмене наследования» // СУ РСФСР. 1918. № 34. Ст. 456. (Утратил силу).

8. Постановление ВЦИК и СНК РСФСР от 29 января 1926 г. «0б отмене максимума наследования и дарения» // СУ РСФСР. 1926. № 10. Ст. 73. (Утратило силу). 
9. Постановление ВЦИК и СНК РСФСР от 28 мая 1928 г. «0 дополнении статьи 422 Гражданского Кодекса Р. С.Ф.С.Р. примечанием 2» / СУ РСФСР. 1928. № 65. Ст. 468. (Утратило силу).

10. Гражданский кодекс Российской Советской Федеративной Социалистической Республики от 31 октября 1922 г. // СУ РСФСР. 1922. № 71. Ст. 904. (Утратил силу).

11. Гражданский кодекс Российской Советской Федеративной Социалистической Республики от 11 июня 1964 г. // Ведомости Съезда народных депутатов и Верховного Совета РСФСР. 1964. № 24. Ст. 406. (Утратил силу).

12. Указ Президиума Верховного Совета СССР от 14 марта 1945 г. «0 наследниках по закону и по завещанию» // Ведомости Съезда народных депутатов и Верховного Совета СССР. 1945. № 15. Ст. 112. (Утратил силу).

13. Рогожкина И. Н. История становления и тенденции развития законодательства о наследовании в России [Электронный pecypc] https://www.garant.ru/ (дата обращения 25.04.2020).

14. Основы гражданского законодательства Союза ССР и республик от 8 декабря 1961 г. // Ведомости Съезда народных депутатов и Верховного Совета СССР. 1961. № 50. Ст. 526. (Утратили силу).

15. Гражданский кодекс Российской Федерации. Часть третья от 26 ноября 2001 г. № 146-Ф3 (ред. 18.03.2019) // Собрание законодательства Российской Федерации. 2001. № 49. ст. 4552.

16. Петров Е. Ю. Наследственное право: постатейный комментарий к статьям 1110-1185, 1224 Гражданского кодекса Российской Федерации. М.: М-Логос, 2018. $656 \mathrm{c}$.

17. Долгушина Д. А. Субъекты наследования по закону в наследственном праве Российской Федерации // Молодой ученый. 2018 . № 43 (229). С. 109-111.

18. Мельникова М. Н. Наследование по закону в России от Свода законов до Гражданского кодекса РСФСР 1964 года: Историко-теоретический аспект: автореф... канд... юр. . . наук. 12.00.01. М., 2001. 33 с.

19. Синайский В.И. Русское гражданское право. Киев: Прогресс, 1917. 638 с.

\footnotetext{
(c) Валевская Ангелина Анатольевна ( a.valevskaya@yandex.ru ).

Журнал «Современная наука: актуальные проблемы теории и практики»
}

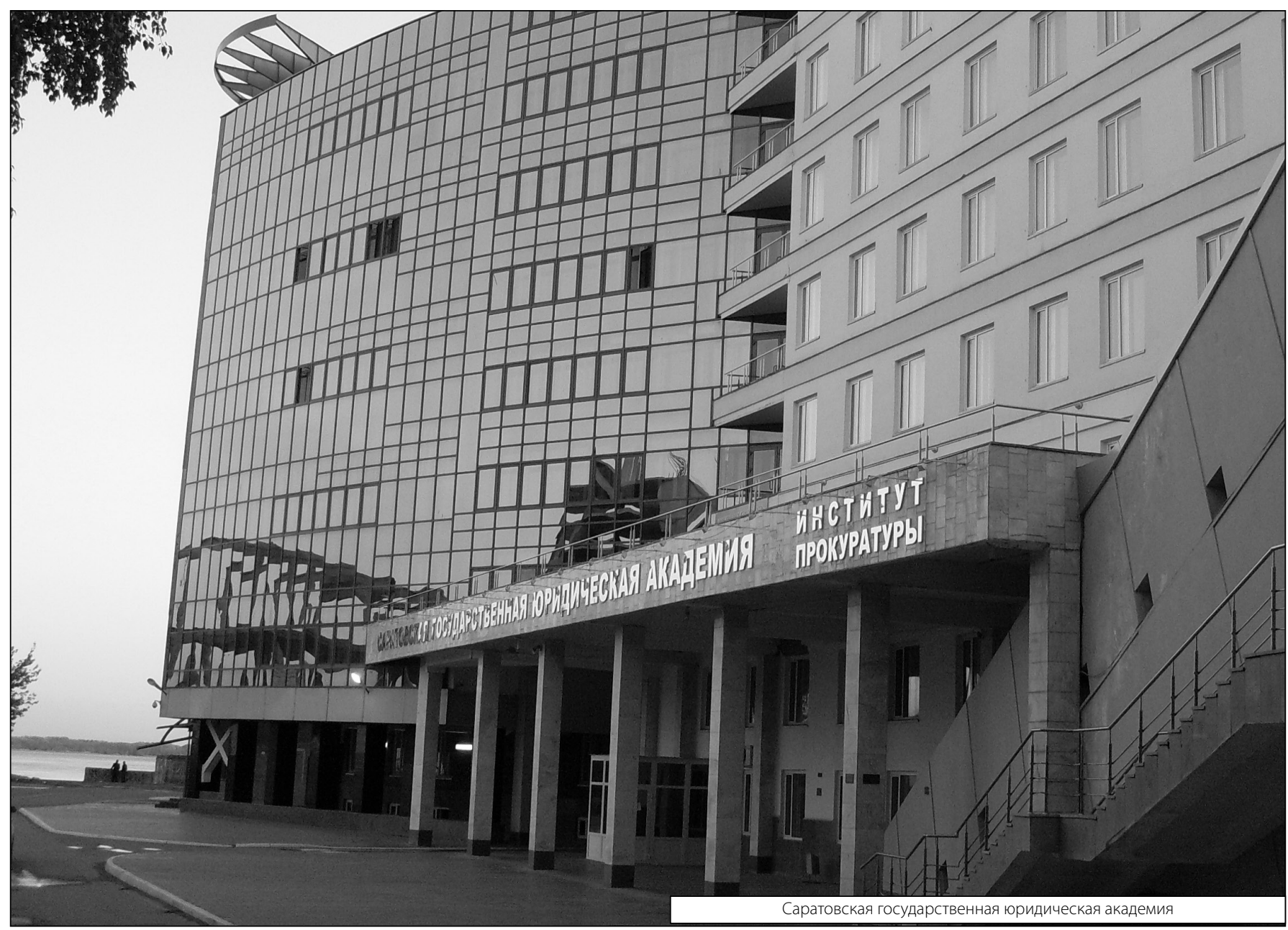

